\title{
Diet and growth of non-native Mississippi silversides and yellowfin gobies in restored and natural wetlands in the San Francisco Estuary
}

\author{
Sahrye E. Cohen ${ }^{1, *}$, Stephen M. Bollens ${ }^{2}$ \\ ${ }^{1}$ Department of Biology and Romberg Tiburon Center for Environmental Studies, San Francisco State University, \\ 3152 Paradise Drive, Tiburon, California 94920, USA \\ ${ }^{2}$ School of Earth and Environmental Sciences, Washington State University Vancouver, \\ 14204 Northeast Salmon Creek Avenue, Vancouver, Washington 98686-9600, USA
}

\begin{abstract}
We examined how wetland restoration status influenced habitat quality for fishes by comparing otolith-calculated growth rates and diets of 2 abundant non-native fish species, the locally transient planktivorous Mississippi silverside Menidia audens and the resident demersal-feeding yellowfin goby Acanthogobius flavimanus, in 2 wetlands undergoing restoration ('restoring' wetlands) and 1 natural wetland (Napa River, San Francisco Estuary, California, USA; $38^{\circ} 10^{\prime} \mathrm{N}_{i} 122^{\circ} 18^{\prime} \mathrm{W}$ ). Native species with similar trophic requirements were too few in abundance to serve as study organisms. Differences in fish diet and growth based on restoration status were expected for the more resident goby species, but not for the transient silversides. Fish were collected in June 2004 and 2005 from a 10 yr old restoring marsh, a 50 yr old restoring marsh and a natural marsh, using a modified fyke net. Diet of silversides was primarily composed of copepods, cumaceans, and flying insects, while yellowfin goby diets were composed of annelids, cumaceans, and amphipods. Prey species biomass in the stomachs of yellowfin gobies was significantly different between marshes, but these differences were not dependent on restoration status. No significant differences in Mississippi silverside growth rates were detected, and yellowfin goby growth rates varied somewhat between marshes and years, but were not significantly different between restored versus reference sites. Based on these findings, we suggest that adequate prey abundance and prey species composition is available for these fish species in both our restored and natural study sites. It also appears that some restoring breached wetlands can quickly (within $10 \mathrm{yr}$ ) provide equivalent habitat to natural areas, at least for generalist, non-native fishes; however, consideration of underlying mechanisms of restoration will be important in designing wetlands that specifically favor native fish populations.
\end{abstract}

KEY WORDS: Acanthogobius flavimanus - Menidia audens $\cdot$ Wetland restoration · Non-native species $\cdot$ Fish ecology $\cdot$ Tidal marsh

Resale or republication not permitted without written consent of the publisher

\section{INTRODUCTION}

Evaluating restoration success is a major goal of wetland restoration and management (Kentula 2000, Thom 2000, Zedler \& Callaway 2000, Thayer \& Kentula 2005). In heavily urbanized coastal regions such as the San Francisco Estuary (SFE), restoration outcomes are expected to satisfy human-related values (i.e. scenic viewsheds, sportfishing, water-based recreation) as well as demonstrate the same level of ecosystem func- tionality (Ehrenfeld 2000) as natural areas. Consequently, researchers and managers have developed numerous methods of monitoring and evaluating wetlands to assess restoration success (Flower 2001, Neckles et al. 2002). Often floristic composition and coverage is the primary measure of restoration success, although other specifically biologic metrics, such as species lists or comparisons of population size between non-native versus native species, are increasingly used to inform both ecological and societal management de- 
cisions in highly altered ecosystems. Fish growth and condition are seldom criteria for evaluating restoration success despite the fact that the recovery of local fish populations is a common restoration target.

Effective restoration efforts require an understanding of not only the abundance of fishes in the restored habitats, but also of the quality of the habitat and its relationship to the growth and health of the species. It is necessary to consider important trophic and food web interactions, such as those between fish and prey (i.e. zooplankton) in shallow and wetland restoration (Perrow et al. 1999). Studies have shown that many salt marsh organisms benefit from trophic subsidies of organic matter originating in adjacent upland and open water habitats (Weinstein et al. 2005). These trophic subsidies may vary in importance to fish and other nekton as additional autochthonous food resources become available to consumers during wetland colonization (Simenstad \& Thom 1996, Jassby \& Cloern 2000). Data from breached wetlands undergoing restoration (henceforth 'restoring' wetlands) in the SacramentoSan Joaquin Delta (upper SFE) suggest that the early stages of restoration provide opportunity and habitat that often supports prey resources for more opportunistic, and often non-native fishes (Simenstad et al. 1999). Although these marshes may be quickly utilized by some fish species, other research on the Delta notes that measuring time since restoration of a wetland is not necessarily a predictive indicator of successful restoration to reference marsh conditions (Grimaldo 2005).

Anthropogenic environmental change in the SFE has enabled the successful colonization of introduced fish and invertebrate species, thereby compromising the community structure and resilience of native species (Meng \& Moyle 1994). Several recently introduced fish species, including the yellowfin goby Acanthogobius flavimanus and Mississippi silverside Menidia audens are common in both restored and reference tidal marsh habitats (Hieb \& Greiner 2001, S. Bollens unpubl. data). Because the goal of wetland restoration in the SFE is to restore natural marsh function, enhancing the populations of native fishes is a crucial characteristic of a successful restoration (Brown 2003). Therefore, more evaluation is needed of both native and non-native fish responses to current restoration efforts.

Ongoing monitoring in SFE wetlands has revealed that the highly abundant non-native yellowfin gobies and Mississippi silversides are common prey items for sport fishes and marsh birds (Moyle 2002). However, these non-native fishes will have wetland food web interactions - such as competition for food resources or consumption of other species' larvae - that may be detrimental to native fishes such as the threatened delta smelt Hypomesus transpacificus (Moyle 2002). Recent research demonstrates that restored tidal fresh- water marshes in the SFE are quickly colonized by large numbers of non-native fishes (Grimaldo et al. 2004), but little research has been conducted in SFE brackish and saltwater systems to discern whether these fishes are as successful in restoring wetlands, in terms of diet and growth, compared to non-altered wetlands. Non-native fishes are not the optimal study organisms for evaluating whether a restoring wetland has returned to its former functionality within an estuarine system, however, studies on these organisms provide information on one of the likely endpoints of restoration in highly altered and urbanized systems.

Nekton utilization of natural, altered, and restored wetlands is well studied in many estuarine areas, particularly the Atlantic coast of North America (Kneib 1997), and increasingly in saltwater and freshwater areas of many other estuarine systems (Le Quesne 2000, Connolly 2005, Rozas et al. 2005, Reed et al. 2006). Many studies have found that in restored wetlands nekton abundance and species diversity is lower, and that the habitat provides fewer benefits compared to natural, unmanaged wetlands (e.g. Hampel et al. 2003, Thom et al. 2004, Rozas et al. 2005). However, some studies suggest that restoring wetlands (Teo \& Able 2003), or even sites invaded by non-indigenous vegetation (Phragmites sp.) (Meyer et al. 2001, Hanson et al. 2002), provide nekton habitat that is equivalent to natural marshes.

The present study sought to determine whether restored wetlands provide significantly better habitat, in terms of diet and growth, for non-native fishes than non-altered wetlands. More specifically, we used growth rates, as calculated from daily otolith increments, and diet analysis of 2 non-native invasive fish species (yellowfin gobies and Mississippi silversides) to assess the relative habitat quality of restoring and reference wetlands in the Napa River system of the SFE. Our study had initially intended to include native species as well, but our sampling yielded too few specimens of native fish to allow for this.

The fish assemblage in the SFE has undergone dramatic changes during the last $150 \mathrm{yr}$, including the addition of many invasive non-native species, such as the fish species used in this study. Since their introduction into the San Francisco Bay and Delta there has been considerable discussion and confusion in determining whether non-native silversides were Menidia audens, the Mississippi silverside, or M. beryllina, the inland silverside (Moyle 2002). As a result of recent research into the morphometric differences of both M. audens and M. beryllina (Suttkus et al. 2005) and discussions among local fisheries experts, the nonnative silverside population of the SFE has been determined to be $M$. audens, the Mississippi silverside (J. L. Grenier and K. Heib pers. comm.). 
Although targeting different prey communities, both the Mississippi silverside and the yellowfin goby are considered to be generalist feeders, a trait that may be important in determining invasion success in a new estuarine habitat (Ruiz et al. 2000). The Mississippi silverside is a planktonic and surface feeder whereas the yellowfin goby is a demersal feeder (Moyle 2002). Adults and older juveniles of both species are considered to be primarily marsh residents. Mississippi silversides are the more transient of the 2 species, vacating individual marsh channels during low tide, whereas post-settlement juvenile gobies (Miyazaki 1940) are primarily benthic and can tolerate much lower tidal water depth in individual channels.

We expected that there would be differences in the diet and growth rate of these fishes between restored and reference wetlands because of differences in prey availability and composition between restoring and reference marshes. Although other investigators have found fish (Fundulus sp.) in some restoring marshes to have greater access to nutritive animal protein (polychaetes) than in comparable natural marshes (Moy \& Levin 1991), other studies have determined that plankton and flying insects are some of the first prey sources to become available in restoring breeched levee wetlands (Merkley et al. 2005), while nutritive and accessible benthic faunal communities develop over time (Matthews \& Minello 1994). Therefore, the specific null hypotheses that we tested in this study were that there was no difference in diet and growth rates of both non-native transient planktonic-feeding Mississippi silversides and the non-native resident demersalfeeding yellowfin goby in restored versus reference wetlands.

\section{MATERIALS AND METHODS}

Study sites. The Napa River is a tributary estuary that flows into San Pablo Bay in the northern part of the SFE. Three wetland sites, Coon Island $\left(38^{\circ} 11^{\prime} 36^{\prime \prime} \mathrm{N}_{\text {; }} 122^{\circ} 19^{\prime} 09^{\prime \prime} \mathrm{W}\right)$, Bull Island (38 $\left.13^{\prime} 03^{\prime \prime} \mathrm{N}_{;} 122^{\circ} 18^{\prime} 17^{\prime \prime} \mathrm{W}\right)$ and Pond 2A $\left(38^{\circ} 09^{\prime} 09^{\prime \prime} \mathrm{N}_{\text {; }} 122^{\circ} 19^{\prime} 10^{\prime \prime} \mathrm{W}\right)$ (Fig. 1), were sampled within this system. Coon Island is a 162.4 ha ancient salt marsh (marsh formation during thousands of years of pre-European settlement) with some portions considered centennial marsh (marsh formation over the last 150 yr due to mining sediment accumulation). This marsh has experienced some anthropogenic impact over time, but was never diked and drained for agricultural use. Bull Island is a 43.8 ha restoring marsh that was formerly leveed and drained for a variety of land uses, including agriculture, and later breached in 1955. Pond 2A is a 215.6 ha restoring marsh and former evaporation salt pond that was breached in 1995.

Salinity levels in the studied wetlands are dependent on tidal influence, precipitation and runoff. The SFE, and consequently San Pablo Bay and the lower Napa River, has mixed, semi-diurnal tides. Concurrent measurements of hydrography and physical processes in Coon Island, Bull Island, and Pond 2A have found a general trend of increasing salinities in the wetlands towards the south as the influence of the freshwater Napa River declines and the influence of the saline San Pablo Bay increases. Therefore, the most northern site, Bull Island, is generally the least saline and the southernmost site, Pond 2A, is generally the most saline, with Coon Island at an intermediate salinity (Siegel et al. 2005). This trend is reinforced seasonally as freshwater flow from the Napa River declines in the summer.

The vegetation community of the lower Napa River wetlands is predominantly composed of Salicornia virginica, Typha angustifolia and Scirpus maritimus. Coon Island and Bull Island have comparable species
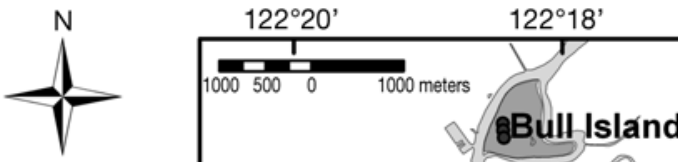

Locations of fyke nets Study sample sites

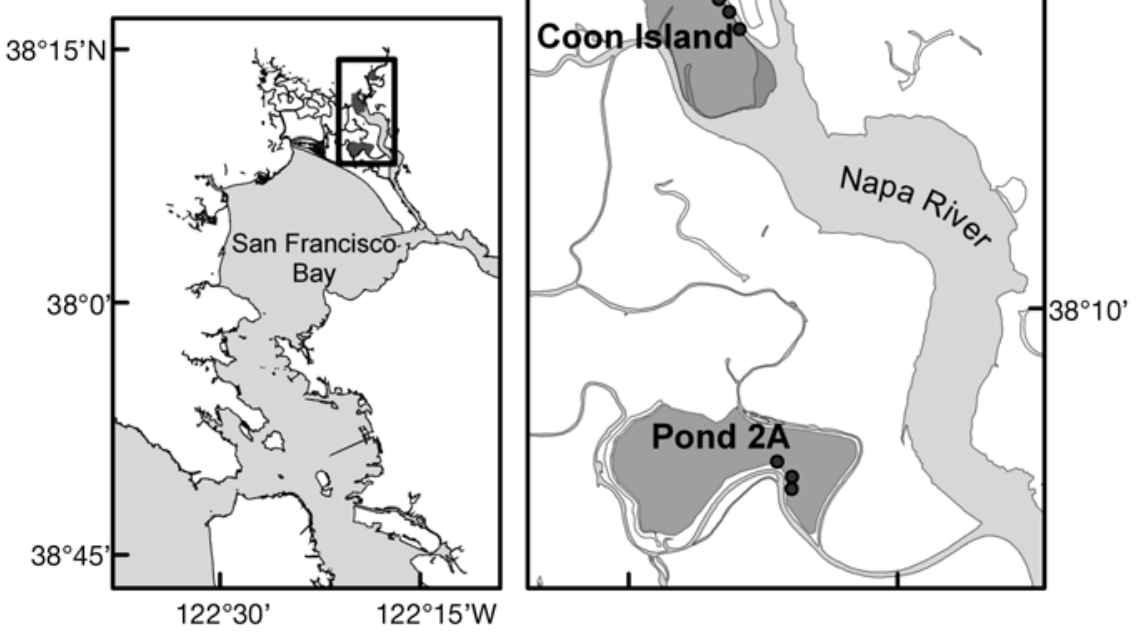

Fig. 1. Study area in the Napa River System within the San Francisco Estuary. Approximate placement of fyke nets in sampling channels (๑) 
occurrences, although the diversity distribution of plant species in Bull Island is patchier than in Coon Island, likely reflecting antecedent conditions. Pond 2A has approximately half the plant species of Coon Island and Bull Island and contains species, including Salicornia europaea and Cotula coronopifola, that are commonly found in newly restored sites (Parker et al. 2005). Additionally, Pond 2A has the lowest elevation and Coon Island has the highest elevation, a factor that - along with others, such as inundation - affects plant distribution and possibly faunal use of the wetland (Parker et al. 2005).

Salinity, temperature, and channel edge. Temperature and salinity for each channel system and sampling period were measured using a YSI ${ }^{\mathrm{TM}}$ (Model 85) at the surface and bottom of each channel at the time and location the fyke net was placed at slack water following the flood tide. Channel edge length (m) was measured by using orthogonal satellite photographs and ArcView GIS software (v. 8.0).

Fish sampling. Fish sampling occurred during the nighttime spring tide at each of the 3 sites in June 2004 and June 2005. We sampled 3 channels in each marsh, with 1 marsh sampled per day on each of 3 consecutive days (18 to 20 June 2004 and 22 to 25 June 2005). Fishes were sampled with modified nylon mesh fyke nets, as described in detail by Visintainer et al. (2006). Briefly, the fyke nets were composed of a mouth, body and cod end in the form of a live trap with $3.2 \mathrm{~mm}$ mesh. Adjustable wings with $6.4 \mathrm{~mm}$ mesh were attached to the mouth of the net and extended to the sides of the channel and onto the marsh plain. Nets were placed at the mouth of each channel approximately $10 \mathrm{~m}$ upstream from the marsh-open water interface and perpendicular to the shore. All nets were set during the post-flood slack tide and recovered at the post-ebb slack tide, and fishes were periodically (approximately every $60 \mathrm{~min}$ ) removed from the cod end throughout the tidal cycle. All channels used in this study completely dewatered during each sampling period.

Fish collected from the 3 channels at each site were combined to produce a single aggregated sample from that site and date. Juvenile Mississippi silversides (15 to $40 \mathrm{~mm}$ fork length [FL]) and yellowfin gobies (20 to $70 \mathrm{~mm}$ total length [TL]) were sorted from each aggregated sample and a random subsample of 50 fish was weighed and measured in the field. Fish were weighed (wet weight [wet wt]) to the nearest $0.01 \mathrm{~g}$ and measured (FL for Mississippi silversides and TL for yellowfin gobies) to the nearest $\mathrm{mm}$. These fish were then anesthetized with MS-222 (tricaine methanesulfonate, Sigma), immediately preserved in $95 \%$ ethanol, and brought back to the laboratory for diet and otolith analysis.
Fish diet analysis. We examined the stomach contents of Mississippi silversides, and yellowfin gobies. In 2004, using a small subsample of fish from the first collection, we performed a prey species-effort analysis to determine the minimum sample size of stomachs needed for analysis of each predator species. This was accomplished by establishing the number of individual fish at which cumulative prey species and average stomach content weight reached an asymptote. Based on visual inspection of the prey species-effort curve, we determined these minimum sample sizes to be 10 fish site $^{-1} \mathrm{yr}^{-1}$ for Mississippi silversides and 15 fish site ${ }^{-1}$ $\mathrm{yr}^{-1}$ for yellowfin gobies (data available upon request).

We selected a random subsample of fish from each sample for diet analysis. The fore-stomach of each fish was removed and the contents extracted, blotted dry and weighed (wet wt) to the nearest $1 \mu \mathrm{g}$. Percent stomach fullness was assessed and assigned a relative index of fullness ( $0=$ empty, $1=25 \%$ full, $2=50 \%$ full, $3=75 \%$ full, $4=100 \%$ full). In addition, digestion of stomach contents was assessed and assigned a relative index $(0=$ no digestion, $1=25 \%$ digested, $2=50 \%$ digested, $3=75 \%$ digested, $4=100 \%$ digested). Prey items from each stomach were identified to the lowest taxonomic category (i.e. species) whenever possible and enumerated using a Leica MZ-6 stereomicroscope (6.3× to $40 \times$ magnification). Each prey taxon was weighed to the nearest $1 \mu \mathrm{g}$. Stomach content weight was normalized by dividing by the individual fish weight to determine the normalized stomach content weight $\left(\mathrm{g} \mathrm{g}^{-1}\right)$. Unequal sample sizes occasionally resulted from low catches on some sample dates.

Otolith analysis. Previous work has validated the daily nature of otolith increment deposition in Menidia beryllina and another Menidia species (Barkman 1978, Gleason \& Bengtson 1996). To our knowledge, no otolith validation work has been reported on yellowfin gobies, although work on numerous other species of gobies, both temperate and tropical, has shown that many Gobiids have daily otolith increments (Iglesias et al. 1997, Hernaman et al. 2000, MacInnis \& Corkum 2000). We attempted validation work on yellowfin gobies in June 2005 but were unable to maintain wildcaught specimens in the laboratory long enough for analysis. However, based on the studies above, we proceed on the assumption that the yellowfin goby deposits daily otolith increments.

We removed the pair of sagittal otoliths from each fish and attached them to microscope slides with clear fingernail polish. Otoliths were polished with 2400 and 3200 grit micromesh sandpaper and microscopy immersion oil to facilitate increment counts and interpretation. Otolith examination followed standard techniques (Secor et al. 1991) and increments on the sagittae were counted using an Olympus light micro- 
scope at $400 \times$ and $1000 \times$ magnification using a polarized filter between the light source and the stage. Daily increments were counted on Mississippi silverside otoliths along their longest radius from the core to the outer edge. Daily increments on yellowfin goby otoliths were counted from the core to a large accessory primordium that was present on all collected otoliths, and then from the origin on that primordium to the edge of the otolith. This accessory primordium may indicate a life history change, such as settlement into the wetland from an open-water environment, as it does in some other demersal fish such as Cottids (Blizard 2000).

All otoliths were read by the same person (S.E.C.). Before increment counts began, all abnormally shaped otoliths and unequally sized sagittae were discarded ( $<2 \%$ of all samples). We made 2 independent readings of each otolith and used criteria similar to those of Searcy \& Sponaugle (2000) to determine which reading was most appropriate to be used in further analysis. The mean of the 2 readings was calculated if the daily increment counts differed by $<10 \%$ from each other. If the daily increment counts differed by $>10 \%$, the otolith was read again, for a third time. If the third count fell within $10 \%$ of one of the previous 2 measurements, the mean of this count and the closest of the previous 2 counts was calculated. If the difference between increment counts remained $>10 \%$ after 3 counts, the otolith was excluded from analysis ( $~ 5 \%$ of total samples).

Statistical analyses. Salinity, temperature and channel edge data for all sites and dates were compared using descriptive statistics and 1-way and 2-way ANOVAs (SPSS v. 11.5).

Stomach content data were analyzed for normality and heterogeneity of variances, and in some cases were logarithmic or inverse transformed to better fit assumptions of normality. We used a 1-way ANOVA to test for differences in stomach fullness indices, content digestion indices, number of prey items per fish, and normalized stomach content weights using wetland site as our factor (Zar 1999). A posteriori tests (Bonferroni and Tukey's HSD) were used to examine differences in means between specific wetland sites.

Otolith length-at-age data were determined to be normally distributed for all samples (SPSS v. 11.5). We used these measurements of relative age and length to calculate growth rates using linear regression (BIOM Stat). ANCOVA (BIOM Stat) was used to test our null hypothesis that there was no difference in growth rates for Mississippi silversides or yellowfin gobies between restored and reference wetlands (Sokal \& Rohlf 1995).

\section{RESULTS}

\section{Salinity, temperature and channel edge}

Salinity was significantly different between restored and reference wetlands during each sampling period (2-way ANOVA, $F=123.64, \mathrm{df}=2, \mathrm{p}<0.001$ ), and was also significantly different between the 2004 and 2005 sampling periods (2-way ANOVA, $F=32623.12$, df $=1$, $\mathrm{p}<0.001)$. The highest salinity for both years was measured at Pond 2A (18.2 in 2004 and 7.4 in 2005), and the lowest was at Bull Island (16.7 in 2004 and 6.6 in 2005). For all sites, salinity in 2004 was approximately 10 higher than in 2005 (Table 1). There was a significant difference in water temperature between wetland sites (2-way ANOVA, $F=10.46$, df $=2, p=0.002$ ) and between sampling years (2-way ANOVA, $F=37.47$, $\mathrm{df}=1, \mathrm{p}<0.001)$, with the highest temperature $\left(19.1^{\circ} \mathrm{C}\right.$ in 2004 and $19.8^{\circ} \mathrm{C}$ in 2005) occurring at Coon Island (reference site) (Table 1). There was also a significant interaction between wetland and sampling year for both salinity (2-way ANOVA, $F=17.37$, df $=2$, p < 0.001 ) and temperature (2-way ANOVA, $F=5.81, \mathrm{df}=$ $2, \mathrm{p}=0.017)$. Channel edge was significantly different between sites (1-way ANOVA, $F=6.03$, df $=2, \mathrm{p}=$ 0.12 ) with the least amount of channel edge, $193.6 \mathrm{~m}$, at Bull Island (Table 1).

In addition to Mississippi silversides and yellowfin gobies, 8 to 12 different species of fishes were collected during our sampling. For all sites and dates, Mississippi silversides and yellowfin gobies were very abundant and together comprised 90 to $95 \%$ of all fishes sampled. Unfortunately, we did not consistently collect a large enough sample of any native fish from all 3 wetland sites to be able to test for differences in diet and growth rate of native fish between restored and reference wetlands.

\section{Stomach content analysis}

Diet composition

Mississippi silversides. Insect parts and Nippoleucon hinumensis (cumacean) were the primary prey by bio-

Table 1. Mean salinity, temperature and channel edge length of sample sites in June 2004 and June 2005

\begin{tabular}{|c|c|c|c|c|c|}
\hline \multirow[t]{2}{*}{ Site } & \multirow[t]{2}{*}{ Edge length (m) } & \multicolumn{2}{|c|}{$2004-$} & \multicolumn{2}{|c|}{$-2005-$} \\
\hline & & Salinity & Temp $\left({ }^{\circ} \mathrm{C}\right)$ & Salinity & Temp $\left({ }^{\circ} \mathrm{C}\right)$ \\
\hline Pond 2A & 780.4 & 18.2 & 18.8 & 7.4 & 19.0 \\
\hline Bull Island & 193.6 & 16.7 & 18.4 & 6.6 & 19.5 \\
\hline Coon Island & 413.3 & 17.2 & 19.1 & 7.1 & 19.8 \\
\hline
\end{tabular}


mass of Mississippi silversides collected from Pond 2A in 2004. $N$. hinumensis and insect parts comprised $97 \%$ of the total prey biomass in fish from Bull Island. Total prey biomass from Coon Island was divided almost evenly in thirds between $N$. hinumensis, insect parts, and unknown organisms (Fig. 2). More taxa were identified in gut contents from 2005 than in those from 2004; these aditional prey items were primarily crustaceans. In 2005, N. hinumensis and insects, along with Eurytemora sp., were common prey items in Pond 2A. Diet from Bull Island was predominantly (65\%) composed of the calanoid copepod, Eurytemora sp., with dietary contributions from insects, amphipods and tanaids. Insects and the tanaid Sinelobus stanfordi were important components of prey biomass in Coon Island channels (Fig. 2).

Yellowfin gobies. In general, the diet of yellowfin gobies included more prey taxa $(\mathrm{n}=17)$ than Mississippi silversides $(\mathrm{n}=9)$. Amphipods, polychaetes, oligochaetes, harpacticoid copepods, cumaceans and tanaids were some of the prey found in stomachs examined from Pond 2A in 2004 (Fig. 3), but no one prey taxon comprised $>39 \%$ of total prey biomass. A large proportion of stomach contents collected from Bull Island was composed of benthic polychaete

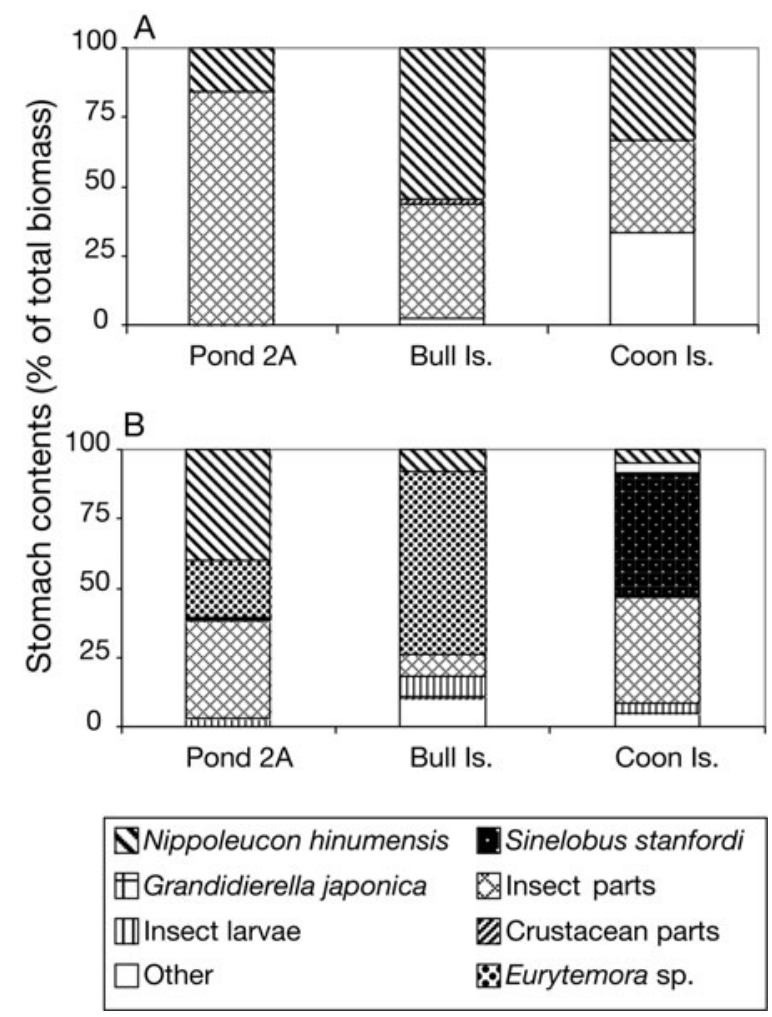

Fig. 2. Menidia audens. Stomach contents composition by weight (\% of total biomass) for (A) June 2004 and (B) June 2005 by wetland site (Pond 2A, Bull Island, Coon Island) worms, including $33 \%$ Neanthes limnicola. In addition to a mix of aquatic amphipods, copepods, and cumaceans, fish collected from Coon Island in 2004 had ingested a large proportion ( $20 \%$ of biomass) of a terrestrial amphipod, Talitridae (Fig. 3). Diet of yellowfin gobies in 2005 contained many of the same prey taxa that were consumed in 2004. Stomach contents of yellowfin gobies from Pond 2A were dominated by Nippoleucon hinumensis $(50 \%)$ and Sinelobus stanfordi $(32 \%)$, while stomach contents from Bull Island remained similar to those from 2004 with a large contribution of benthic worms. Stomach contents from Coon Island were similar to those collected in 2004 and had a large percentage by biomass of terrestrial Talitridae amphipods (35\%) (Fig. 3).

\section{Normalized stomach content weight}

Normalized stomach content weight for Mississippi silversides ranged from a mean of $1.2 \times 10^{-3}\left(\mathrm{~g} \mathrm{~g}^{-1}\right)$ from Pond 2A in 2004 to $7.0 \times 10^{-3}\left(\mathrm{~g} \mathrm{~g} \mathrm{~g}^{-1}\right)$ in 2005 . These Mississippi silverside normalized stomach content weights were not significantly different between restored and reference wetlands in either 2004

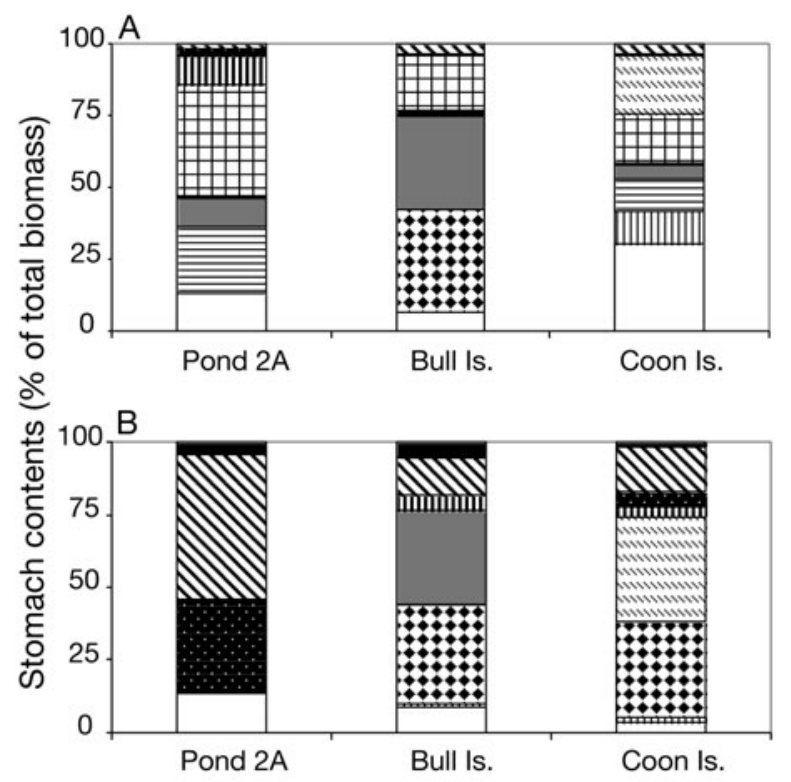

\begin{tabular}{|ll}
\hline Nippoleucon hinumensis & Sinelobus stanfordi \\
WGnorimosphaeroma insulare & Thalitridae amphipod \\
界Grandidierella japonica & Coullana canadensis \\
$\square$ Neanthes limnicola & Polychaetes \\
OOligochaetes & Insect larvae \\
$\square$ Other &
\end{tabular}

Fig. 3. Acanthogobius flavimanus. Stomach contents composition by weight (\% of total biomass) for (A) June 2004 and (B) June 2005 by wetland site (Pond 2A, Bull Island, Coon Island) 
(ANOVA, $F=0.2, \mathrm{df}=21, \mathrm{p}=0.822$ ) or 2005 (ANOVA, $F=0.96$, df $=38, \mathrm{p}=$ 0.392) (Fig. 4). Yellowfin goby normalized stomach content weight ranged from a mean of $10^{-3}\left(\mathrm{~g} \mathrm{~g} \mathrm{~g}^{-1}\right)$ for gobies from Pond $2 \mathrm{~A}$ in 2005 to $8.7 \times 10^{-3}\left(\mathrm{~g} \mathrm{~g}^{-1}\right)$ for gobies from Bull Island in 2005. Wetland site did significantly influence normalized stomach content weight for yellowfin gobies in both 2004 (ANOVA, $F=$ 6.4, $\mathrm{df}=66, \mathrm{p}=0.003$ ) and 2005 (ANOVA, $F=9.53$, df $=52, \mathrm{p}<0.001$ ), but not in a consistent pattern related to restoration status. Pond $2 \mathrm{~A}$, a restored site, had a significantly lower mean normalized stomach content weight for 2004 and 2005 than either Bull Island, the other restored site, or Coon Island, the reference site. When the means were compared we found that the greatest normalized stomach content weight of yellowfin gobies was found in Bull Island, followed by Coon Island, and then Pond 2A (Fig. 4).

Number of individual prey per fish

Number of prey items per Mississippi silverside was greater in 2005 with a minimum mean of 3.9 items (Coon
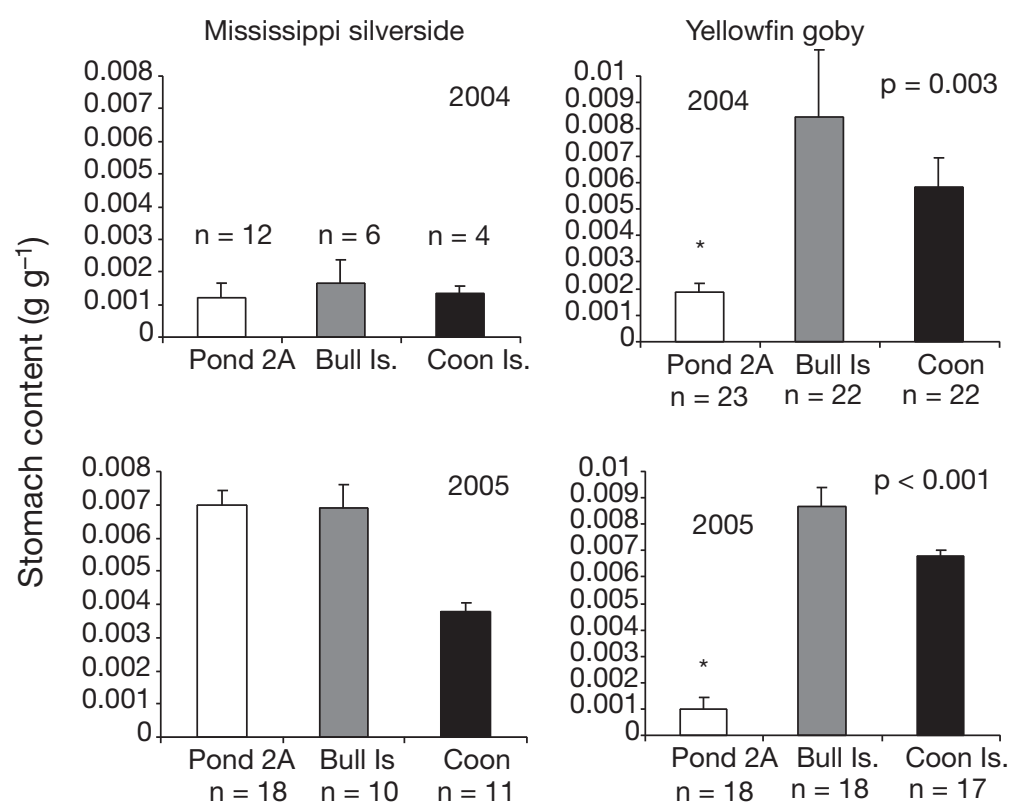

Fig. 4. Menidia audens and Acanthogobius flavimanus. Mean normalized stomach content weight $(\mathrm{g})$ of Mississippi silversides and yellowfin gobies in June 2004 and June 2005. ${ }^{*}$ Significant. Error bars: + SE
Island) and a maximum mean of 20.3 items (Bull Island). Wetland site influenced the number of prey per fish, but was only significant in 2005 (Fig. 5). Number of prey items per fish was not significantly different for Mississippi silversides in 2004 (ANOVA, $F=2.26, \mathrm{df}=21, \mathrm{p}=0.13$ ), but was significant in 2005 (ANOVA, $F=4.79$, df $=34, \mathrm{p}=$ 0.015). Mean number of prey items in fish from Bull Island, a restored site, was significantly higher than the mean number in Coon Island, a reference site. The mean number of prey items per fish was also lower in Coon Island than at the Pond 2A (restored site). Number of prey items per individual fish also was not significantly different for yellowfin gobies in different marshes collected during 2004 (ANOVA, $F=0.18$, df $=46, \mathrm{p}=0.24$ ), but was significantly different among marshes for those collected in 2005 (ANOVA, $F=8.36$, df = $47, \mathrm{p}=0.001$ ). For yellowfin gobies, the mean number of prey items was significantly greater in Coon Island (30.1 items), the reference site, than in restoring sites, Pond 2A (2.5 items), and Bull Island (24.7 items) (Fig. 5).

Number of prey taxa per fish

The mean number of prey taxa per fish was not significantly different for 
most sites in 2004 and 2005 (Fig. 6). Only among Mississippi silversides sampled in 2004 was there a significant difference between wetland sites (ANOVA, $F=$ 5.47, df $=2, \mathrm{p}=0.015$ ), being less at Pond 2A (1 taxon fish $^{-1}$ ) than at the other restored site, Bull Island (1.5 taxa fish ${ }^{-1}$ ), but not significantly different than that at Coon Island (1 taxon fish ${ }^{-1}$ ), the reference site. In 2005, silversides at Bull Island also had the greatest mean number of prey taxa (2.4 taxa fish $\left.{ }^{-1}\right)$, but this was not significantly different than at the other sites (Pond 2A, 1.94 taxa fish ${ }^{-1}$ and Coon Island, 1.82 taxa fish $^{-1}$ ) (ANOVA, $F=1.03, \mathrm{df}=2, \mathrm{p}=0.37$ ). Yellowfin gobies in Pond 2A had the lowest mean number of prey taxa per fish for both 2004 (1.5 taxa fish ${ }^{-1}$ ) and 2005 (1.6 taxa fish $\left.^{-1}\right)$, but the results were not significantly different from other sites for either year. In 2004, yellowfin gobies in Bull Island had the greatest mean number of prey taxa per fish (2.18 taxa fish $\left.{ }^{-1}\right)$, while in 2005 the greatest number was found in gobies from Coon Is. (2.4 taxa fish ${ }^{-1}$ ) (Fig. 6).

\section{Stomach fullness index}

Wetland site and restoration status did not influence the stomach fullness of either Mississippi silversides or yellowfin gobies. Stomach fullness indices for Mississippi silversides were greater in 2005 than in 2004 and ranged from a mean of 1 (25\% full) for fish from Coon Island in 2004 to a mean of 2.7 (almost $75 \%$ full) for fish from Bull Island in 2005. Stomach fullness indices for yellowfin gobies were similar in both 2004 and 2005 and ranged from a mean of 1.4 (between 25 to $50 \%$ full) for fish from Pond 2A in 2005 to a mean of 1.9 (almost 50\% full) for fish from Bull Island in 2005. Stomach fullness indices were not significantly different for Mississippi silversides in 2004 (ANOVA, $F=$ $2.71, \mathrm{df}=21, \mathrm{p}=0.092$ ) or 2005 (ANOVA, $F=0.50, \mathrm{df}=$ $38, \mathrm{p}=0.61)$. Similarly, stomach fullness indices were not significantly different for yellowfin gobies in 2004 (ANOVA, $F=0.62, \mathrm{df}=66, \mathrm{p}=0.54$ ) or 2005 (ANOVA, $F=1.62, \mathrm{df}=52, \mathrm{p}=0.21$ ).

\section{Gut contents digestion index}

Consistent with stomach fullness scores, wetland site and restoration status did not appear to influence the digestion index (not shown) of either Mississippi silversides or yellowfin gobies. Gut contents digestion indices for Mississippi silversides were similar in both 2004 and 2005 and ranged from a mean of 2.7 (almost $75 \%$ digested) for fish from Pond 2A in 2004 to a mean of 3.5 (between 75 to $100 \%$ digested) for fish from Coon Island in 2004. Digestion indices for yellowfin gobies were also similar for both 2004 and 2005 with a range of 2.5 (between 50 to $75 \%$ digested) for gobies from Bull Island in 2005 and 3.1 (75\% digested) for gobies from Pond 2A in 2005. Gut contents digestion indices were not significantly different for Mississippi silversides in 2004 (ANOVA, $F=1.37$, $\mathrm{df}=21, \mathrm{p}=0.28$ ) or 2005 (ANOVA, $F=0.036$, df =38, $p=0.97$ ). Gut content digestion indices were also not significantly different for yellowfin gobies in 2004 (ANOVA, $F=0.45, \mathrm{df}=66, \mathrm{p}=$ 0.64 ) or 2005 (ANOVA, $F=2.01$, df $=52$, $\mathrm{p}=0.14)$.

\section{Otolith analysis}

Mississippi silversides

We used a linear regression to describe growth for the juvenile Mississippi silversides collected in this study. Regression slopes (ANCOVA, $F=2.03$, $\mathrm{df}=142, \mathrm{p}=0.14$ ) and adjusted mean growth rates (ANCOVA, $F=0.82, \mathrm{df}=$ 144, $\mathrm{p}=0.44$ ) of Mississippi silversides from all sites and sampling years were not significantly different, indicating that regression lines and intercepts are also not significantly different. Therefore, there was no significant difference in growth rate between Mississippi sil-
Fig. 6. Menidia audens and Acanthogobius flavimanus. Mean number of prey taxa from stomach contents of Mississippi silversides and yellowfin gobies in June 2004 and June 2005. *Significant. Error bars: + SE 
versides collected from restored versus reference wetlands. The mean growth rate for Mississippi silversides from 2004 and 2005 was $0.24 \mathrm{~mm} \mathrm{~d}^{-1}$ (Fig. 7).

\section{Yellowfin gobies}

Using ANCOVA, we found that data sets could not be combined across years for analysis because for some sites either the slope (Coon Island, $F=9.29, \mathrm{df}=$ $74, \mathrm{p}=0.003$ ) or intercepts (Bull Island, $F=4.29, \mathrm{df}=$ $66, p=0.042)$ were significantly different between years. The mean growth rate of yellowfin gobies in 2004 was greatest at Bull Island $\left(0.61 \mathrm{~mm} \mathrm{~d}^{-1}\right)$ and least at Coon Island $\left(0.25 \mathrm{~mm} \mathrm{~d}^{-1}\right)$. In 2004, both regression slopes (ANCOVA, $F=4.16, \mathrm{df}=82, \mathrm{p}=0.019$ ) and intercepts (ANCOVA, $F=6.93, \mathrm{df}=84, \mathrm{p}=0.0016$ ) of yellowfin gobies were significantly different between wetland sites, indicating that growth rates were different (Fig. 8, Table 2).

The mean growth rate of yellowfin gobies in 2005 was the greatest at Pond $2 \mathrm{~A}\left(0.55 \mathrm{~mm} \mathrm{~d}^{-1}\right)$ and least at Bull Island $\left(0.40 \mathrm{~mm} \mathrm{~d}^{-1}\right)$. In 2005, regression slopes (ANCOVA, $F=2.52, \mathrm{df}=140, \mathrm{p}=0.084$ ) were not significantly different, but intercepts (ANCOVA, $F=$ $8.439, \mathrm{df}=142, \mathrm{p}=0.0003$ ) were significantly different for yellowfin gobies sampled from all sites (Fig. 9, Table 2).

\section{DISCUSSION}

Our results indicate that the restored wetlands on the Napa River provide habitat and resources for yellowfin gobies and Mississippi silversides that are com-

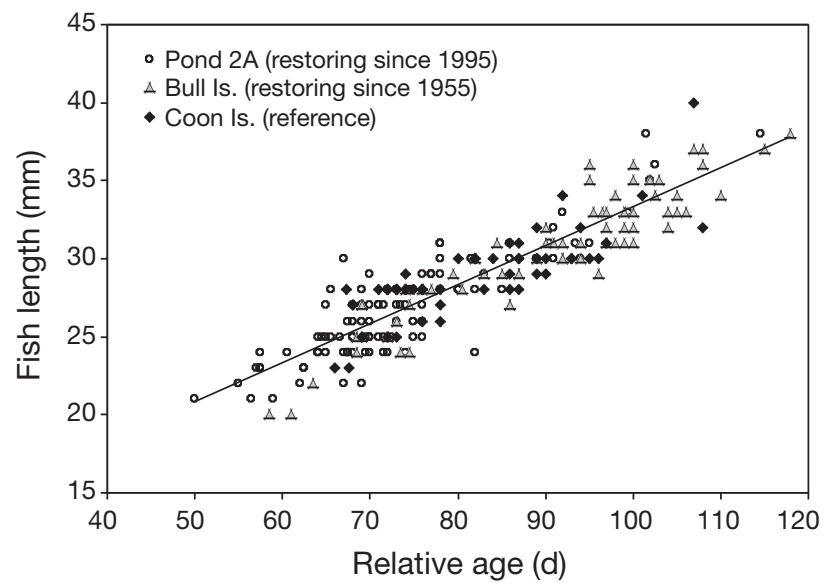

Fig. 7. Menidia audens. Regression line describing growth rate (age versus length) of Mississippi silversides from both restoring and reference wetland sites in June 2004 and June 2005. Regression slopes and intercepts of individual sites and sampling years were not significantly different. The pooled regression equation is fish length $(\mathrm{mm})=0.24$ relative age (d) $+9.09 ; r^{2}=0.787, p<0.001$

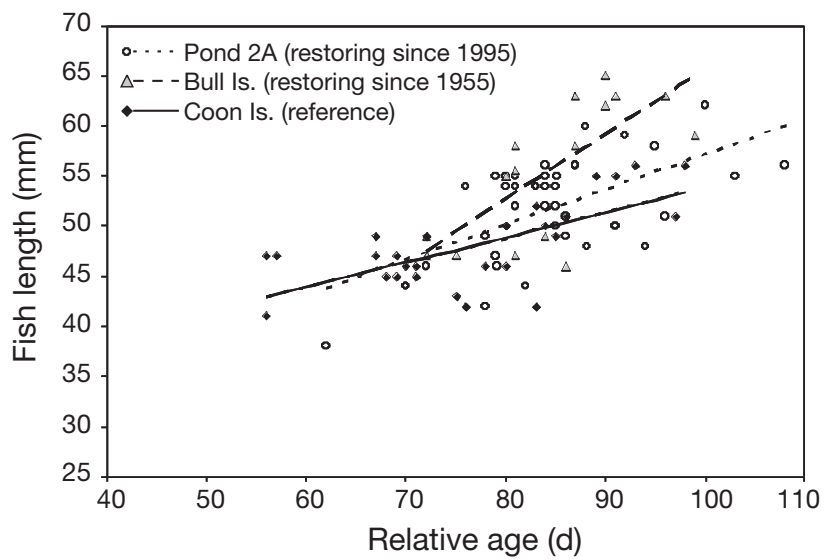

Fig. 8. Acanthogobius flavimanus. Regression lines describing growth rate of yellowfin gobies from both restoring and reference wetland sites in June 2004. Regression slopes and intercepts of individual sites were found to be significantly different. Regression equations and $\mathrm{r}^{2}$ values are listed in Table 2

Table 2. Acanthogobius flavimanus. Standard length (adjusted mean $\pm \mathrm{SD}$ ) regression equations and $\mathrm{r}^{2}$ values for yellowfin gobies in June 2004 and June 2005

\begin{tabular}{|lclc|}
\hline $\begin{array}{l}\text { Year and } \\
\text { site }\end{array}$ & $\begin{array}{c}\text { Standard length } \\
(\mathrm{mm})\end{array}$ & Regression & $\mathrm{r}^{2}$ \\
\hline $\mathbf{2 0 0 4}$ & & & \\
Pond 2A & $48.6 \pm 0.63$ & $y=0.43 x+15.9$ & 0.361 \\
Bull Island & $53.1 \pm 1.09$ & $y=0.61 x+4.4$ & 0.542 \\
Coon Island & $48.8 \pm 0.64$ & $y=0.25 x+29.2$ & 0.466 \\
2005 & & & \\
Pond 2A & $46.9 \pm 0.56$ & $y=0.55 x+4.66$ & 0.799 \\
$\begin{array}{l}\text { Bull Island } \\
\text { Coon Island }\end{array}$ & $50.3 \pm 0.70$ & $y=0.4 x+18.6$ & 0.490 \\
& $49.2 \pm 0.48$ & $y=0.44 x+14.4$ & 0.758 \\
\hline
\end{tabular}

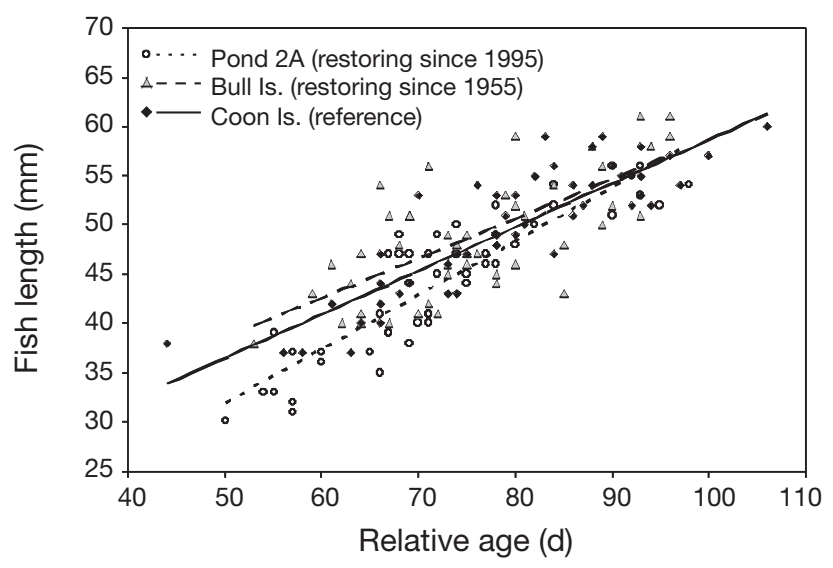

Fig. 9. Acanthogobius flavimanus. Regression lines describing growth rate of yellowfin gobies from both restoring and reference wetland sites in June 2005. Regression slopes of individual sites were not significantly different, but intercepts of individual sites were significantly different. Regression equations and $r^{2}$ values are listed in Table 2 
parable to habitat in a natural wetland in the same river system. Although these non-native fishes may not be the optimal organisms to assess restoration of the former functionality of these wetlands, this study provides analysis of one outcome of restoration in a highly impacted, urbanized estuary. While some differences in diet and prey biomass were observed, overall no significant patterns were found that would suggest different utilization of restored versus references sites by gobies and silversides. Similarly, otolith-calculated growth rates of yellowfin gobies varied somewhat between marshes and years but were not significantly different in restored wetlands versus reference wetlands. Even less difference was found in growth rates of Mississippi silversides, which did not significantly vary between either year or wetland type.

Diet composition of Mississippi silversides in this study was somewhat different than that found in previous studies of these fish in both their native habitats (Stickney \& McGeachin 1978) and elsewhere in San Francisco Bay (Simenstad et al. 1999, Grimaldo et al. 2004, Visintainer et al. 2006). Our expectation for the highly motile, transient Mississippi silverside was that the diet of these fish would be primarily plankton with some input from terrestrial neustonic insects. We found that with the exception of the planktonic copepod, Eurytemora sp., Mississippi silversides consumed mainly epibenthic (copepods and tanaids) or neustonic (insects) prey. Although our results contain some of the same prey taxa reported in other studies of Mississippi silversides collected during summer (e.g. planktonic copepods at night and insects during the day) (Stickney \& McGeachin 1978, Moyle 2002), our study showed a greater input of potentially autochthonous prey than previous studies. Yellowfin goby diet composition in our study was more consistent with that found in previous studies in their natural range (Kanou et al. 2004) and in San Francisco Estuary (Simenstad et al. 1999, Grimaldo et al. 2004, Visintainer et al. 2006). Yellowfin goby diets were more varied and higher in taxa richness than Mississippi silverside diets and contained predominantly benthic or epibenthic prey, including gammarid amphipods, cumaceans, tanaids and polychaete worms.

Diets of both Mississippi silversides and yellowfin gobies in this study included prey species generally considered to be terrestrial (adult forms of flying insects, Talitridae amphipods), indicating that these fish have access to submerged and emergent vegetation on the channel edge and marsh plain during high tide, or that these prey are available on the surface of the water. Studies examining nekton use in restored and natural marshes (Minello et al. 1994, Peterson \& Turner 1994, West \& Zedler 2000) have established that fish with tidal access to the channel edge and marsh plain are more numerous and have fuller stomachs and contain more additional prey types than those fish with restricted access to these habitats. Nekton utilization research in a South African estuary corroborated these findings and showed that fish feeding in intertidal creeks was a critical link in the transfer of production from vegetated marsh surfaces to subtidal habitats (Le Quesne 2000).

There were some significant differences in yellowfin goby prey biomass between marshes (fish from Pond 2A had significantly lower biomass for both 2004 and 2005), but these differences lacked a coherent pattern and were not correlated with restoration status of the marsh. Yellowfin gobies collected from Bull Island, the older of the restored sites, had greater prey biomass (normalized stomach content weight) than the other sites. Fish collected from Pond 2A, the younger restored site, had significantly lower prey biomass than fish from both Bull Island and the reference wetland, Coon Island. Other studies that have compared fish diet in both restored and natural wetlands (Miller \& Simenstad 1997, Llanso et al. 1998) suggest that different infaunal prey found in restored versus reference wetlands might not restrict the habitat utilization of a generalist feeder. Mississippi silversides and yellowfin gobies are both considered as generalist feeders, a characteristic that may be a component of success in occupying a new estuarine habitat (Ruiz et al. 2000), and that would therefore be expected to aid fish in exploiting new food resources in restoring habitats. The large variety of prey and average stomach fullness $(\sim 50 \%$ full) found in this study suggests that both restored and reference wetland sites provide a ready source of acceptable prey for these generalist fishes.

We found no significant difference in otolith-calculated growth rate of Mississippi silversides among any of the marshes, and no consistent difference in otolithcalculated growth rate of yellowfin gobies between restored and natural wetlands. The lack of significant difference between any Mississippi silverside growth rates, whether compared between years, sites or restoration status, suggests that these wetland habitats provide similar conditions for non-native fish growth, or that these transient fish are able to move between marshes in the same system. Fish use of intertidal rivulets and creekbanks as corridors within marshes has been well established (Rozas et al. 1988, Weinstein et al. 2005). It is possible that the natural marsh in this study, Coon Island, is accessible to fish from one of the restored sites, Pond $2 \mathrm{~A}$, through other altered wetland areas during the high tide. However, the other restoration site, Bull Island, is separated from these 2 sites by the leveed main channel of the Napa River, making it less likely that there is an exchange of free-swimming juvenile fish between this and other marshes. Numer- 
ous estuarine and salt marsh studies have shown that both juveniles and adults of several wetland species display strong site fidelity to local intertidal marsh creeks (Potthoff \& Allen 2003, Teo \& Able 2003, Skinner et al. 2005). Concurrent investigation of the wetland food web at our study sites using stable isotopes also suggests that both yellowfin gobies and Mississippi silversides display some measure of site fidelity and that fish diet bases at Bull Island were significantly different than those at Coon Island and Pond 2A (Howe \& Simenstad 2005).

The pattern of differences in growth rates of yellowfin gobies are difficult to characterize. Analysis of fish collected in 2004 indicated significant differences in both adjusted means and growth rates of fish from different sites, while analysis of fish collected in 2005 indicated that only differences in adjusted means were significant. We also observed interannual variation in the slopes of our growth rate regressions. Growth rates in 2004 were highest in the 2 restored sites while in 2005 the restored site with the highest 2004 growth rate was the lowest and the reference site had intermediate growth rates. Although yellowfin goby larvae are pelagic in brackish water, later juveniles settle into localized areas, swimming only short distances until they must move within the estuary to brackish water for breeding (Moyle 2002). The life history characteristics of these fish make it likely that the differences we observed in their diet and growth are a result of residence after settlement within a wetland site rather than a result of the fish moving between sites to utilize resources from other wetlands. Despite some variation between sites and years, yellowfin gobies appear to grow equally well in restored and natural wetlands in the Napa River system.

During the summer season there is salinity gradient in the Napa River, such that Bull Island has the lowest salinity, followed by Coon Island, and with Pond 2A having the highest salinity of all 3 sites. While we did not measure for salinity in this study, we feel that the biological sampling did not show an obvious response to the gradient salinity. If there was a noticeable salinity effect, we would expect that visual analysis of the graphs of either the diet or otolith data would show a trend of site arrangement by salinity gradient. This effect was not demonstrated by any of the diet data and is of potential concern in only one of 3 analyses of otolith data. In both the diet and otolith analysis there was no obvious trend that demonstrated an effect of salinity that would explain the diet and growth rate results of Mississippi silversides and yellowfin gobies in this study.

Our findings suggest that restored marshes in Napa River are equivalent to natural non-altered wetlands in terms of Mississippi silverside and yellowfin goby diet and growth. This is likely due to the adequate prey resources available to both resident and transient fishes within a wetland area rather than to extensive exchange of juveniles and adults between wetlands. In their isotopic analyses, Howe \& Simenstad (2005) found that allochthonous phytoplankton contributes a comparatively very small amount to the food web of these fishes, while material derived from wetland plants provides a larger contribution. Vegetation at the reference site, Coon Island, and one restored site, Bull Island, are similar, with some slight vegetation differences primarily due to wetland elevation, while there are somewhat more vegetative differences at Pond 2A, the restored site with the lower elevation (Parker et al. 2005). At all 3 of these sites the dominant vegetation is Scirpus maritimus, although Coon Island also has a codominant of Salicornia virginica, especially on the marsh plain. Coon Island, the natural reference wetland, also had the most vegetation diversity, the best defined assemblages, and the highest elevation of all the sites in this study. Bull Island and Pond 2A are both lower in elevation, and the youngest (most recent) restoring marsh (Pond 2A) has the least species diversity and elevation indicating that it is still actively maturing as a marsh (Williams \& Orr 2002, Parker et al. 2005). These small differences in developing wetland vegetation may account for the diversity of prey available to these generalist fish. These results are similar to some other recent breeched-levee restoration projects (Nemerson \& Able 2005) in which prey quantity and availability seemed to be adequate in all wetland sites. Even considering the significantly lower prey biomass in our most recently restored site (Pond 2A), the differences we detected in diet do not seem to promote greater growth of fish in specific wetlands.

Development trajectories are a way to describe the increasing complexity and species richness found in restoring wetlands over time. Simenstad \& Thom (1996) found that total invertebrate species richness as well as the diversity of associated fishes increased during the first 7 years of a restoring wetland. In a longer, 25 yr assessment of a North Carolina salt marsh, Craft et al. (1999) found that above-ground biomass of vegetation reached equivalency with the reference site within $10 \mathrm{yr}$, while the benthic community took longer (between 15 to $25 \mathrm{yr}$ ) to reach an equivalent level. Other studies conducted in Southern California restoring wetlands have suggested that it may take as many as 40 yr for restored wetlands to be functionally equivalent to natural marshes (Zedler \& Callaway 1999, Callaway 2005). Several other studies have shown that some limited components, such as equal utilization by nekton (Roman et al. 2002) and similar food resources, can develop in a much shorter time in already vegetated restoring wetlands, even before changes in dom- 
inant vegetation occur (James-Pirri et al. 2001). The similar diet and growth of both resident and transient fish in our study suggest that while some restoration may continue, these restoring sites in the Napa River system at their current stages of restoration (10 yr and 50 yr) provide similar habitat quality for yellowfin gobies and silversides as a fully mature wetland. However, as other researchers have cautioned (Moy \& Levin 1991), wetlands should not be considered to be replaceable resources in the short term.

Our results have important implications for restoration in many estuarine systems. A number of recent papers have questioned the goals of wetland restoration in urbanized estuaries (Simenstad et al. 2005, 2006) and whether created marshes are adequately achieving their habitat goals (Zedler \& Callaway 1999, Callaway 2005, Hilderbrand et al. 2005). In this study, we have shown that for the metrics of growth and diet, restored wetlands can relatively quickly (10 yr) provide habitat equivalent to natural areas for 2 extremely common, generalist and non-native fishes. While non-native fishes are not the optimal study organisms for evaluating whether a restoring wetland has returned to its former trophic functionality, studies on these organisms provide information on one of the likely endpoints of restoration in highly altered and urbanized systems. There is no doubt that the species in this study and many other non-natives have become incorporated into the ecosystem of the San Francisco Estuary (Matern et al. 2002) and are widely represented in both restoring and natural wetlands throughout the system. Although we have not determined whether the success, in terms of diet and growth, of these non-native species in restoring wetlands is precluding the optimal use of these sites by native species, it is worth evaluating the results of this study in the context of the numerous goals and outcomes desired of a restoration project. If a goal of restoration is to create wetland habitat that increases functionality while providing less than optimal habitat to non-native species, so as to hopefully inhibit their populations, then the breach-levee wetlands that have developed at Bull Island and Pond 2A have not entirely succeeded. It is possible that these 2 restoring wetlands will continue on a development trajectory that will result in similar elevation and vegetation assemblages to the natural wetland, Coon Island. However, as evidenced by growth rates and diet analysis, the resulting mature habitat will continue to provide adequate resources to these widespread invasive fish species, rather than limiting their range and impact on the overall ecosystem. Future research should determine food web interactions and habitat utilization by native and non-native estuarine fishes to aid in designing restoration that considers habitat overlap and co-occurrence of native and non-native species, with the ultimate goal of creating conditions that optimize habitat quality for native species.

Acknowledgements. We thank S. Avent, D. Gewant, S. Gifford, E. Howe, B. Mohammad, K. Papastephanou, H. Rodriguez for field assistance and J. Toft and T. Visintainer for help with stomach content analysis procedures and invertebrate identification. T. Laidig and J. Hobbs were generous with their time and assistance in otolith procedures and analysis, and R. Larson and C. Simenstad provided vital planning and advice throughout the project. We also thank D. Gewant for calculating channel edge lengths, S. Obrebski for generous assistance with statistical analysis and A. Slaughter for lab and manuscript assistance. This project was funded by a CALFED grant to S.M.B.

\section{LITERATURE CITED}

Barkman RC (1978) The use of otolith growth rings to age young Atlantic Silversides, Menidia menidia. Trans Am Fish Soc 107:790-792

Blizard R (2000) Life histories and otolith microstructure variation of intertidal sculpins (Family: Cottidae). MS thesis, San Francisco State University, San Francisco, CA

Brown LR (2003) Will tidal wetland restoration enhance populations of native fishes? In: Brown LR (ed) Issues in San Francisco tidal wetlands restoration. San Francisco Estuary and Watershed Science 1:2. Available at: http:// repositories.cdlib.org/cgi/viewcontent.cgi?article=1003\& context=jmie/sfews

Callaway JC (2005) The challenge of restoring functioning salt marsh ecosystems. J Coast Res 40:24-36

Connolly RM (2005) Modification of saltmarsh for mosquito control in Australia alters habitat use by nekton. Wetl Ecol Manag 13:149-161

Craft C, Reader J, Sacco JN, Broome SW (1999) Twenty-five years of ecosystem development of constructed Spartina alterniflora (Loisel) marshes. Ecol Appl 9:1405-1419

Ehrenfeld JG (2000) Evaluating wetlands within an urban context. Ecol Eng 15:253-265

Flower RJ (2001) Change, stress, sustainability and aquatic ecosystem resilience in north African wetland lakes during the 20th century: an introduction to integrated biodiversity studies within the CASSARINA Project. Aquat Ecol 35:261-280

Gleason TR, Bengtson DA (1996) Size-selective mortality of Mississippi silversides: evidence from otolith microstructure. Trans Am Fish Soc 125:860-873

Grimaldo LF (2005) Diet and carbon sources of fishes from open water, edge, and SAV habitats in restored freshwater wetlands of the San Francisco Estuary. MS thesis, San Francisco State University, San Francisco, CA

Grimaldo LF, Miller RE, Peregrin CM, Hymanson ZP (2004) Spatial and temporal distribution of native and alien ichthyoplankton in three habitat types of the SacramentoSan Joaquin Delta. Am Fish Soc Symp 39:81-96

Hampel H, Cattrijsse A, Vincx M (2003) Habitat value of a developing estuarine brackish marsh for fish and macrocrustaceans. ICES J Mar Sci 60:278-289

Hanson SR, Osgood DT, Yozzo DJ (2002) Nekton use of a Phragmites australis marsh on the Hudson River, New York, USA. Wetlands 22:326-337

Hernaman V, Munday PL, Schlappy ML (2000) Validation of otolith growth-increment periodicity in tropical gobies. 
Mar Biol 137:715-726

Hieb K, Greiner T (2001) Fish communities of San Francisco Bay tidal marshes. In: Abstracts. 16th Estuarine Research Federation Conference, FL. Available at: www.erf.org/ cgi-bin/conference_abstract.pl? conference=erf2001\&id=390

Hilderbrand RH, Watts AC, Randle AM (2005) The myths of restoration ecology. Ecol Society 10:19. Available at: www.ecologyandsociety.org/vol10/iss1/art19

Howe E, Simenstad C (2005) Resident vs. transient: an isotopic determination of fish food-web origins in the San Francisco Bay Estuary. In: Abstracts. 7th Biennial State of the San Francisco Estuary Conference, Oakland, CA. Available at: www.irwm.org/files/emilyhoweSOEposter.pdf

Iglesias M, Brothers EB, Morales-Nin B (1997) Validation of daily increment deposition in otoliths. Age and growth determination of Aphia minuta (Pisces: Gobiidae) from the northwest Mediterranean. Mar Biol 129:279-287

James-Pirri MJ, Raposa KB, Catena JG (2001) Diet composition of mummichogs, Fundulus heteroclitus, from restoring and unrestricted regions of a New England (USA) salt marsh. Estuar Coast Shelf Sci 53:205-213

Jassby AD, Cloern JE (2000) Organic matter sources and rehabilitation of the Sacramento-San Joaquin Delta (California, USA). Aquat Conserv 10:323-352

Kanou K, Sano M, Kohno H (2004) Food habits of fishes on unvegetated tidal mudflats in Tokyo Bay, central Japan. Fish Sci 70:978-987

Kentula ME (2000) Perspectives on setting success criteria for wetland restoration. Ecol Eng 15:199-209

Kneib RT (1997) The role of tidal marshes in the ecology of estuarine nekton. Oceanogr Mar Biol Annu Rev 35: 163-220

Le Quesne WJF (2000) Nekton utilization of intertidal estuarine marshes in the Knysna estuary. Trans R Soc S Afr 55: 205-214

Llanso RJ, Bell SS, Vose FE (1998) Food habits of Red Drum and Spotted Seatrout in a restored mangrove impoundment. Estuaries 21:294-306

- MacInnis AJ, Corkum LD (2000) Age and growth of round goby Neogobius melanostomus in the Detroit River. Trans Am Fish Soc 129:852-858

Matern SA, Moyle PB, Pierce LC (2002) Native and alien fishes in a California estuarine marsh: twenty-one years of changing assemblages. Trans Am Fish Soc 131:797-816

Matthews GA, Minello TJ (1994) Technology and success in restoration, creation and enhancement of Spartina alterniflora marshes in the United States. Decision analysis series no. 2, NOAA National Marine Fisheries Service, Galveston, TX

Meng L, Moyle PB (1994) Changes in abundance and distribution of introduced fishes of Suisun marsh. Trans Am Fish Soc 123:498-507

Merkley D, Burrows F, McTigue T, Foret J (2005) Restoration monitoring of coastal marshes. In: Thayer GW, McTigue TA, Bellmer RJ, Burrows FM and others (eds) Sciencebased restoration monitoring of coastal habitats, Vol 2. Decision analysis series no. 23, NOAA Coastal Ocean Program, Silver Spring, MD

Meyer DL, Johnson JM, Gill JW (2001) Comparison of nekton use of Phragmites austrailius and Spartina alterniflora marshes in the Chesapeake Bay, USA. Mar Ecol Prog Ser 209:71-84

Miller JA, Simenstad CA (1997) A comparative assessment of a natural and created estuarine slough as rearing habitat for juvenile chinook and coho salmon. Estuaries 20: 792-806

Minello TJ, Zimmerman RJ, Medina R (1994) The importance of edge for natant macrofauna in a created salt marsh. Wetlands 14:184-198

Miyazaki I (1940) Studies on the Japanese common goby, Acanthogobius flavimanus (Temminck and Schlegel). Bull Jpn Soc Sci Fish 9:159-180

Moy LD, Levin LA (1991) Are Spartina marshes a replacable resource? A functional approach to evaluation of marsh creation efforts. Estuaries 14:1-16

Moyle PB (2002) Mississippi fishes of California. University of California Press, Berkeley, CA

> Neckles HA, Dionne M, Burdick DM, Roman CT, Buchsbaum R, Hutchins E (2002) A monitoring protocol to assess tidal restoration of salt marshes on local and regional scales. Restor Ecol 10:556-563

> Nemerson DM, Able KW (2005) Juvenile sciaenid fishes respond favorably to Delaware Bay marsh restoration. Ecol Eng 25:260-274

Parker VT, Schille L, Vasey M, Callaway J (2005) Comparative vegetation development in different aged brackish tidal wetlands along the lower Napa River, San Francisco Estuary, CA. In: Abstracts 7th Biennial State of the San Francisco Estuary Conference, Oakland, CA. Available at: www.irwm.org/files/Napa_poster.pdf

> Perrow MR, Jowitt AJD, Stansfield JH, Phillips GL (1999) The practical importance of the interactions between fish, zooplankton and macrophytes in shallow lake restoration. Hydrobiologia 395/396:199-210

Peterson GW, Turner RE (1994) The value of salt marsh edge vs. interior as a habitat for fish and decapod crustaceans in a Louisiana tidal marsh. Estuaries 17:235-262

Potthoff MT, Allen DM (2003) Site fidelity, home range, and tidal migrations of juvenile pinfish, Lagodon rhomboides, in salt marsh creeks. Environ Biol Fishes 67:231-240

Reed DJ, Peterson MS, Lezina BJ (2006) Reducing the effects of dredged material levees on coastal marsh function: sediment deposition and nekton utilization. Environ Manage 37:671-685

> Roman CT, Raposa KB, Adamowicz SC, James-Pirri MJ, Catena JG (2002) Quantifying vegetation and nekton response to tidal restoration of a New England salt marsh. Restor Ecol 10:450-460

Rozas LP, McIvor CC, Odum WE (1988) Intertidal rivulets and creekbanks: corridors between tidal creeks and marshes. Mar Ecol Prog Ser 47:303-307

Rozas LP, Caldwell P, Minello TJ (2005) The fishery value of salt marsh restoration projects. J Coast Res 21:37-50

Ruiz GM, Fofonoff PW, Carlton JT, Wonham MJ, Hines AH (2000) Invasion of coastal marine communities in North America: apparent patterns, processes and biases. Annu Rev Ecol Syst 31:481-531

Searcy SP, Sponaugle S (2000) Variable larval growth in a coral reef fish. Mar Ecol Prog Ser 206:213-226

Secor DH, Dean JM, Laban EH (1991) Manual for otolith removal and preparation for microstructural examination. Electric Power Research Institute \& Belle Baruch Institute for Marine Biology and Coastal Research, Chesapeake Biological Laboratory, Solomons, MD

Siegel SW, Bachand PAM, Lowe J, Carson T and others (2005) Physical processes: inundation, datums, salinity, channel geometry. In: Abstracts 7th Biennial State of the San Francisco Estuary Conference, Oakland, CA. Available at: www.irwm.org/files/IRWM-PhysProc-Poster_SciConf_ 2005-1003trc.pdf

Simenstad C, Toft J, Higgins H, Cordell J and others (1999) Preliminary results from the Sacramento-San Joaquin Delta breached levee wetland study (BREACH). Interagency Ecological Program Newsletter 12:15-21. 
Available at: http://iep.water.ca.gov/report/newsletter/ 1999fall/1999fall.pdf

Simenstad C, Tanner C, Crandell C, White J, Cordell J (2005) Challenges of habitat restoration in a heavily urbanized estuary: evaluating the investment. J Coast Res 21:6-23

Simenstad CA, Reed D, Ford M (2006) When is restoration not? Incorporating landscape-scale processes to restore self-sustaining ecosystems in coastal wetland restoration. Ecol Eng 26:27-39

Simenstad CA, Thom RM (1996) Functional equivalent trajectories of the restored Gog-Le-Hi-Te estuarine wetland. Ecol Appl 6:38-56

Skinner MA, Courtenay SC, Parker WR, Curry RA (2005) Site fidelity of mummichogs (Fundulus heteroclitus) in an Altantic Canadian Estuary. Water Qual Res J Can 40: 288-298

Sokal RR, Rohlf FJ (1995) Biometry, 3rd edn. WH Freeman, New York

Stickney RR, McGeachin RB (1978) Food habits of fishes associated with marshland developed on dredged material. Proc Annu Conf Southeast Assoc Fish Wildl Agencies 32:547-560

Suttkus RD, Thompson BA, Blackburn JK (2005) An analysis of the Menidia complex in the Mississippi River Valley and in 2 nearby minor drainages. Southeastern Fishes Council Proc 48:1-9

Teo SLH, Able KW (2003) Habitat use and movement of the mummichog (Fundulus heteroclitus) in a restored salt marsh. Estuaries 26:720-730

Editorial responsibility: Robert Feller,

Columbia, South Carolina, USA
Thayer GW, Kentula ME (2005) Coastal restoration: Where have we been, where are we now, where should we be going? J Coast Res 40:1-5

Thom RM (2000) Adaptive management of coastal ecosystem restoration projects. Ecol Eng 15:365-372

Thom CSB, Peyre MKGL, Nyman JA (2004) Evaluation of nekton use and habitat characteristics of restored Louisiana marsh. Ecol Eng 23:63-75

> Visintainer TA, Bollens SM, Simenstad C (2006) Community composition and diet of fishes as a function of tidal channel geomorphology. Mar Ecol Prog Ser 321:227-243

Weinstein MP, Litvin SY, Guida VG (2005) Considerations of habitat linkages, estuarine landscapes, and the trophic spectrum in wetland restoration design. J Coast Res 40: $51-63$

- West JM, Zedler JB (2000) Marsh-creek connectivity: fish use of a tidal salt marsh in southern California. Estuaries 23:699-710

Williams PB, Orr MK (2002) Physical evolution of restored breached levee salt marshes in the San Francisco Bay Estuary. Restor Ecol 10:527-542

Zar JH (1999) Biostatistical analysis, 4th edn. Prentice Hall, Upper Saddle River, NJ

Zedler JB, Callaway JC (1999) Tracking wetland restoration: Do mitigation sites follow desired trajectories? Restor Ecol 7:69-73

Zedler JB, Callaway JC (2000) Evaluating the progress of engineered tidal wetlands. Ecol Eng 15:211-225

Submitted: October 24, 2006; Accepted: May 6, 2008

Proofs received from author(s): September 13, 2008 